\title{
Evaluation of molecular model-based discovery of ecto-5'-nucleotidase inhibitors on the basis of X-ray structures
}

\author{
Norbert Furtmann*, Jürgen Bajorath \\ From 9th German Conference on Chemoinformatics \\ Fulda, Germany. 10-12 November 2013
}

Ecto-5'-nucleotidase (e5NT) belongs to the family of metallophosphoesterases, hydrolyses AMP to adenosine, and is a regulator of the adenosine signaling pathway [1]. It has been shown, that free adenosine is involved in various diseases and cancer progression [2,3]. In a previous study, a molecular model of e5NT has been created and used for the identification of new sulfonamide inhibitors [4]. Recently, X-ray structures of human e5NT in complex with different inhibitors were published [5]. This made it possible to reevaluate the model building and virtual screening efforts in detail. An extensive analysis of the comparative e5NT model, built using a bacterial enzyme in the presence of $35 \%$ sequence identity as a template, showed that the model was topologically correct and had high accuracy within the active site region. Comparative docking studies were carried out to explore inhibitor binding characteristics within the X-ray structure and the model. The results provided plausible explanations for the successful identification of new e5NT inhibitors by model-based virtual screening and highlighted important parameters [6].

Published: 11 March 2014

\section{References}

1. Zimmermann $\mathrm{H}$, Zebisch $\mathrm{M}$, Sträter N: Cellular function and molecular structure of ecto-nucleotidases. Purinergic Signalling 2012, 8:437-502.

2. Deaglio S, Robson SC: Ectonucleotidases as regulators of purinergic signalling in thrombosis, inflammation, and immunity. Adv Pharmacol 2011, 61:301-332.

3. Zhang B: CD73: a novel target for cancer immunotherapy. Cancer Res 2010, 70:6407-6411.

Department of Life Science Informatics, B-IT, LIMES Program Unit Chemical Biology and Medicinal Chemistry, Rheinische Friedrich-Wilhelms-Universität, Dahlmannstrasse 2, D-53113 Bonn, Germany

(C) 2014 Furtmann and Bajorath; licensee Chemistry Central Ltd. This is an Open Access article distributed under the terms of the Creative Commons Attribution License (http://creativecommons.org/licenses/by/2.0), which permits unrestricted use, distribution, and reproduction in any medium, provided the original work is properly cited. The Creative Commons Public Domain Dedication waiver (http://creativecommons.org/publicdomain/zero/1.0/) applies to the data made available in this article, unless otherwise stated.
4. Ripphausen $P$, Freundlieb $M$, Brunschweiger $A$, Zimmermann $H$, Müller $C E$, Bajorath J: Virtual screening identifies novel sulfonamide inhibitors of ecto-5'-nucleotidase. J Med Chem 2012, 55:6576-6581.

5. Knapp K, Zebisch M, Pippel J, El-Tayeb A, Müller CE, Sträter N: Crystal structure of the human ecto-5'-nucleotidase (CD73): insights into the regulation of purinergic signaling. Structure 2012, 20:2161-2173.

6. Furtmann N, Bajorath J: Evaluation of molecular model-based discovery of ecto-5'-nucleotidase inhibitors on the basis of X-ray structures. Bioorg Med Chem

doi:10.1186/1758-2946-6-S1-P13

Cite this article as: Furtmann and Bajorath: Evaluation of molecular model-based discovery of ecto-5'-nucleotidase inhibitors on the basis of X-ray structures. Journal of Cheminformatics 2014 6(Suppl 1):P13.
Publish with ChemistryCentral and every scientist can read your work free of charge

"Open access provides opportunities to our colleagues in other parts of the globe, by allowing anyone to view the content free of charge."

W. Jeffery Hurst, The Hershey Company.

- available free of charge to the entire scientific community

- peer reviewed and published immediately upon acceptance

- cited in PubMed and archived on PubMed Central

- yours - you keep the copyright

Submit your manuscript here:

http://www.chemistrycentral.com/manuscript/ 